\title{
Giresun İli Yangın İstatistiklerinin İncelenmesi (2011-2016)
}

\author{
İlknur BEKEM KARA \\ Artvin Çoruh Üniversitesi, Borçka Acarlar Meslek Yüksekokulu, Artvin, Türkiye
}

Sorumlu Yazar: ilknurbekem@artvin.edu.tr

Geliş Tarihi: 14.05.2017

Kabul Tarihi: 12.09 .2017

\section{Özet}

$\mathrm{Bu}$ çalışmada, Giresun'da meydana gelen yangın olaylarına ait istatistikler 2011-2016 periyodunda ele alınmış olup, yangınların yıllara göre dağılımı, yanan yerin inşa malzemesine göre cinsi, itfaiyenin yangına müdahale durumu ve yangın çıkış nedenleri araştırılmıştır. 2012 yılı örneklem alınarak yangınların aylara göre istatiksel dağılımı oluşturulmuştur. Ayrıca, tüm yangınlar içinde en büyük orana sahip olan ev yangınları irdelenmiştir. Sonuç olarak 2011-2016 yılları arasında Giresun ilinde toplam 842 adet yangın olayının meydana geldiği, yangın çıkış nedenlerinde ilk sırada elektrik kontağının, ikinci sırada ise baca tutuşmasının yer aldığı, yangınların \% 43'ünün başlangıçta söndürüldüğü, 2012 yılının ilk 3 ayında baca yangınlarının fazla olduğu, ev yangınlarının çoğunun betonarme yapılarda meydana geldiği tespit edilmiştir. Son olarak, yangın olaylarının azaltılması ile ilgili önerilerde bulunulmuştur.

Anahtar Kelimeler: Yangın, İstatistik, Giresun.

\section{Investigation of Giresun Fire Statistics (2011-2016)}

\begin{abstract}
In this study, fire statistics in Giresun were considered in 2011-2016 period, distribution of fires by years, burning place according to the building material, fireman's intervention situation and the causes of fire exits have been researched. Statistical distribution of fires by month was established taking the sample of 2012. In addition, home fires, which have the greatest amount of all fires, are examined. As a result, A total of 842 fire incidents took place in Giresun between 2011 and 2016, in the first place for the reasons of fire exit, the electrical contact, in the second place the chimney burning takes place, $43 \%$ of the fires were initially extinguished, in the first 3 months of the 2012 year, the chimney fires are high, most of the house fires have been found in reinforced concrete structures. Finally, proposals have been made for the reduction of fire incidents.
\end{abstract}

Keywords: Fire, Statistic, Giresun. 


\section{Giriş}

İstatistik kavramı "Bir sonuç çıkarmak için verileri yöntemli bir biçimde toplayıp sayı olarak belirtme işi”" ve "İlkelerini olasılık kuramlarından alarak eldeki verileri grafik ve sayı biçiminde değerlendirmeye dayandıran matematiğin uygulamalı dalı, sayım bilimi” olarak tanımlanmaktadır (Türk Dil Kurumu, 2017). Bir bilim olarak istatistiğin temel görevlerinden biri, geçmiş ve şimdiki durumla ilgili toplanmış sayısal verileri, geliştirilmiş olan bazı tekniklerle analiz ederek gelecek hakkında karar vermemizi kolaylaştırmaktadır (Yıldızbakan, 2001). Yangın istatistikleri; yangın yönetmeliklerini anlamak, yangın olaylarının çıkmasını önlemek ve yangın kontrol yeteneğini geliştirmek açısından önemli bir faktördür. Türkiye'de tüm yangın istatistiklerine dair resmi bir kurum tarafından basılmış ya da yayınlanmış genel bir doküman bulunmamaktadır. Her il belediyesinde bulunan İtfaiye Daire Başkanlıkları'nda ya da İtfaiye Müdürlükler'inde yangın istatistikleri tutulmakta ve bunlardan bazıları belediyelerin web sitelerinde yayınlanmaktadır. Oysa diğer ülkelerde geçmişten günümüze yangın istatistikleri ile ilgili pek çok detaylı çalışma yapılmış ve yapılmaya devam edilmektedir.

2016 yılında yayınlanan 43 ülkenin içerisinde yer aldığı Dünya yangın istatistikleri raporunda; yangın sayıları, yangın oranları, yangınlara bağlı olarak meydana gelen sivil-itfaiye personeli ölüm ve yaralanma vakalarına ilişkin 2010-2014 yıllarına ait sayısal verilerin olduğu görülmektedir. Örnek olarak; 2010 yılında 43 ülkede toplam 3164060 adet yangın olayı meydana gelmiştir. En büyük oran Amerika'ya aitken, bu istatistiğe giren ülkelerden bazıları Rusya, Japonya, Almanya, İtalya ve Ukrayna'dır. 2010-2014 yıllarında ortalama olarak yılda 21000 kişi yangın olaylarında hayatını kaybetmiştir (Brushlinsky ve ark., 2016).

Amerika'da 2015 yılında 1345500 adet yangın olayı meydana gelmiş, bu yangınlarda 3280 sivil hayatını kaybetmiş, 15700 sivil yaralanmıştır. Her 86 saniyede bir ev yangının meydana geldiği belirlenmiştir (NFPA, 2017). 2010-2014 yılları arasında Amerika'da meydana gelen ev yangınları incelendiğinde \% 46'sının yangın çıkış sebebinin mutfakta bulunan pişirme ekipmanları (ocak, fırın vb.) olduğu tespit edilmiştir (Ahrens, 2016).

Türkiye'de 1998-2008 y1lları arasında meydana gelen yangınların toplam sayıs1 929165'tir. Bu yangınların çıkış sebepleri incelendiğinde; en büyük oranın yüzde 30 ile "sigara ve kibrit" olduğu görülmüştür. Çıkış sebeplerinde ikinci sırayı ise yüzde 19'luk oran ile "elektrik tesisatı" kaynaklı yangınlar almaktadır. Ayrıca, 1999-2008 yılları arasında Türkiye'de meydana gelen yangınlarda toplam 3237 kişi hayatını kaybetmiştir (Bekem ve ark., 2011).

Dikkatsizlik yüzünden çıkan yangınların sebepleri arasında özellikle sigara başta gelmektedir. İstanbul'da 1964 senesinde meydana gelen 1481 yangından 365'inin sigaradan çıkmış olduğu istatistiklerle sabittir. Ülke çapında ise 1982-1983 yılında çıkan 23506 yangından 4560 tanesinin 
yine sigara izmaritlerinden çıkmış olduğu tespit edilmiştir. Sigara ateşinin ortalama sıcaklık derecesi $800^{\circ} \mathrm{C}$ civarında olup, söndürülmeden atılan sigaranın yanıcı, patlayıcı ve parlayıcı maddelere teması neticesinde yangın olayı meydana gelmektedir. Söndürmeden yere atılan bir izmaritin, rüzgâr tesirli sürüklenerek temas ettiği yanıcı maddeyi tutuşturduğu bir gerçektir (Bursa Büyükşehir Belediyesi, 2011).

2016 yılı İzmir'de meydana gelen yangın istatistikleri incelendiğinde \% 14,9'unun elektrikten kaynaklandığı tespit edilmiştir (İzmir İtfaiye Daire Başkanlığı, 2017). Elektrik tesisatı ve elektrikli cihazlardan kaynaklanan yangınların nedenleri; tesisatlarının standartlara uygun yapılmaması ve uygun malzeme kullanılmaması, tesisatlarda sonradan yapılan eklemeler, çalışma olmayacağ zaman elektriklerin şalterden kapatılmaması, elektrik lambası, kablolar ve açma kapama düğmelerinde oluşan arızalar, kullanıcı hataları; ütünün fişte bırakılması, elektrikli 1sıtıcıların yakınında çamaşır gibi yanıcı maddelerin bulundurulması, elektrikli aletlerin talimatına uygun kullanmaması, kablolarda meydana gelen erimeler, sigortaların hatalı sarımı ve kullanımı ve aşırı yükleme yapılması olarak sayılabilmektedir (İstanbul Büyükşehir Belediyesi, 2015).

Kocaeli İtfaiyesi tarafından 2009 yılında 224 baca yangının meydana geldiğini, 2010 yılının ilk 8 aylık döneminde 156 baca yangınına müdahale edildiğini ve baca yangınlarının en çok ocak, şubat, mart ve nisan aylarında meydana geldiğini belirtilmiştir (Kocaeli Büyükşehir belediyesi, 2010). Bacalarda oluşan birikintiler, yağlı atıklar ve endüstri atıklarının bulundukları ortamda tutuşması yangın olayını beraberinde getirmektedir. Kendi kendine tutuşmanın nedenleri; "bacaların uygun yapılmaması, yer kazanmak için müşterek bacaların tercih edilmesi, dış duvarlar üzerinden yapılmaması, bacanın fazla meyilli olması, bacada çatlak oluşması, dâhili gaz çıkışına sebep olacak sert köşelerin oluşması, baca temizliklerinin ve kontrolünün yapılmaması, temizleme amacıyla bacaların yakılması" olarak sayılmaktadır (İstanbul Büyükșehir Belediyesi, 2015).

Bursa Büyükşehir Belediyesi tarafindan yayınlanan istatistiklerde Nisan 2014 ayında 440 göreve çıkılmış olup, bunların 91'inin ev yangını, 33'ünün iş yeri, 38'inin araç yangını olduğu rapor edilmiştir. Yapılan tetkiklerde, yangınların 106'sının kimliği belirsiz kişi veya kişilerce çıkarıldı̆̆ı tespit edilmiştir (Bursa Büyükşehir Belediyesi, 2014). Bir ya da daha fazla kişi tarafından, kişi veya kişilerin doğrudan can ve/veya malına zarar vermek üzere kasıtlı olarak çıkartılan yangınlar kundaklama ya da sabotaj kapsamında değerlendirilmektedir. Dünyada Amerika kundakçılıkta ilk sırayı almaktadır. Son 10 yılda yaklaşık olarak 500000 civarında kundakçılık olayı gerçekleşmiştir (Alkış, 2002).

\section{Materyal ve Metot}


$\mathrm{Bu}$ çalışmada Giresun il merkezine ait son 6 yıllık yangın istatistikleri; yangın sayılarının yıllık dağılımı, yanan yere ilişkin bilgiler, yangın çıkış sebepleri, itfaiyenin yangına müdahale durumu, aylara göre yangın sayısı dağılımı açısından incelenmiştir. Ayrıca; tüm yangınlar içinde en fazla yeri olan ev yangınlarına ilişkin istatistikler irdelenmiştir. Sayısal veriler Giresun Belediyesi İtfaiye Müdürlüğ̈̈'nden temin edilmiştir.

\section{Bulgular ve Tartışma}

Giresun'da 2011-2016 periyodunda meydana gelen yangınların yıllık dağılımı Şekil 1'de görülmektedir. 6 yıllık süreçte toplam 842 adet yangın olayı meydana gelmiştir. Yıllık ortalama yangın sayısı 140'tır.

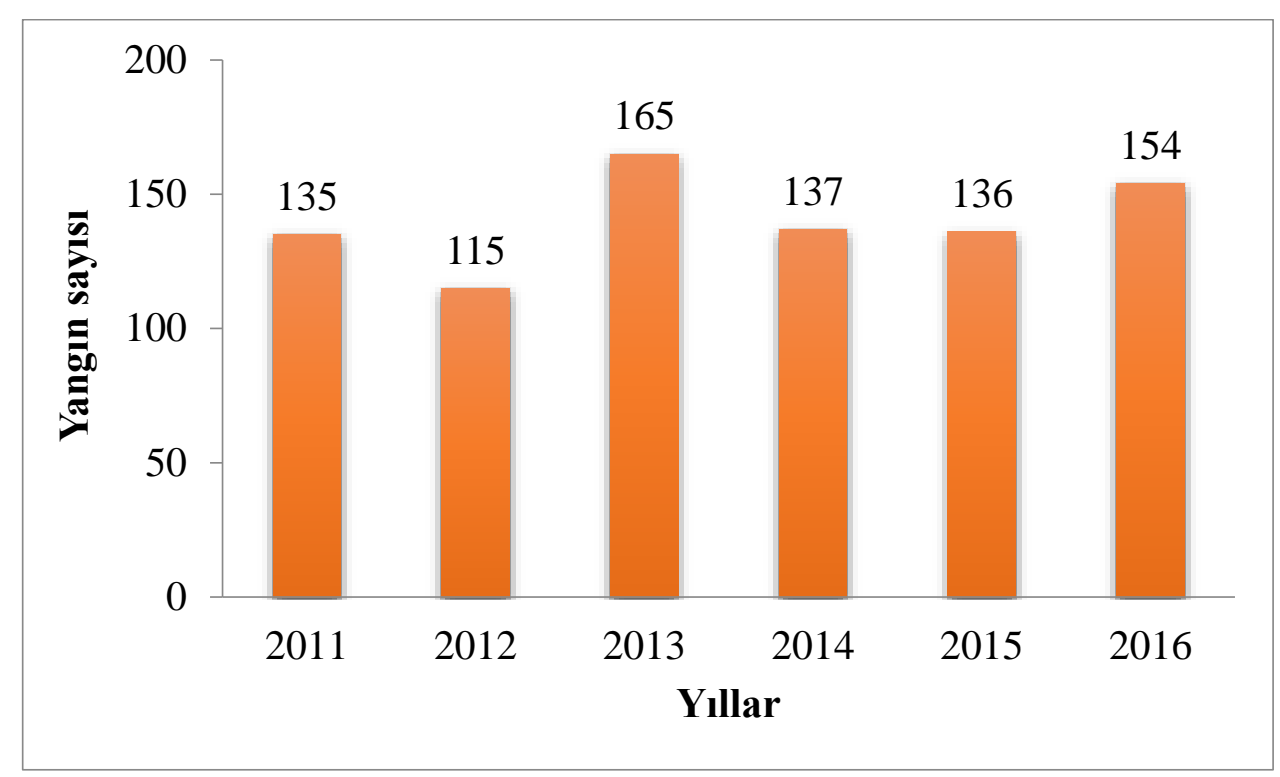

Şekil 1. Yangın sayılarının yıllık dağılımı.

Giresun'da meydana gelen yangınların türlerine göre dağılımı Şekil 2'de verilmiştir (20112016). Meydana gelen toplam 842 yangın olayının \% 35'ini ev yangınları meydana getirmektedir. İkinci sırada ise \% 26'lık oran ile baca yangınları bulunmaktadır. İş yeri ve araç yangınlarının oranı 6 yıllık süreçte \% 10’luk dilimleri meydana getirmektedir. "Diğer" maddesinde bahsedilen yangın yerleri hurda, moloz, atık çöp vb. yangın olaylarıdır. 


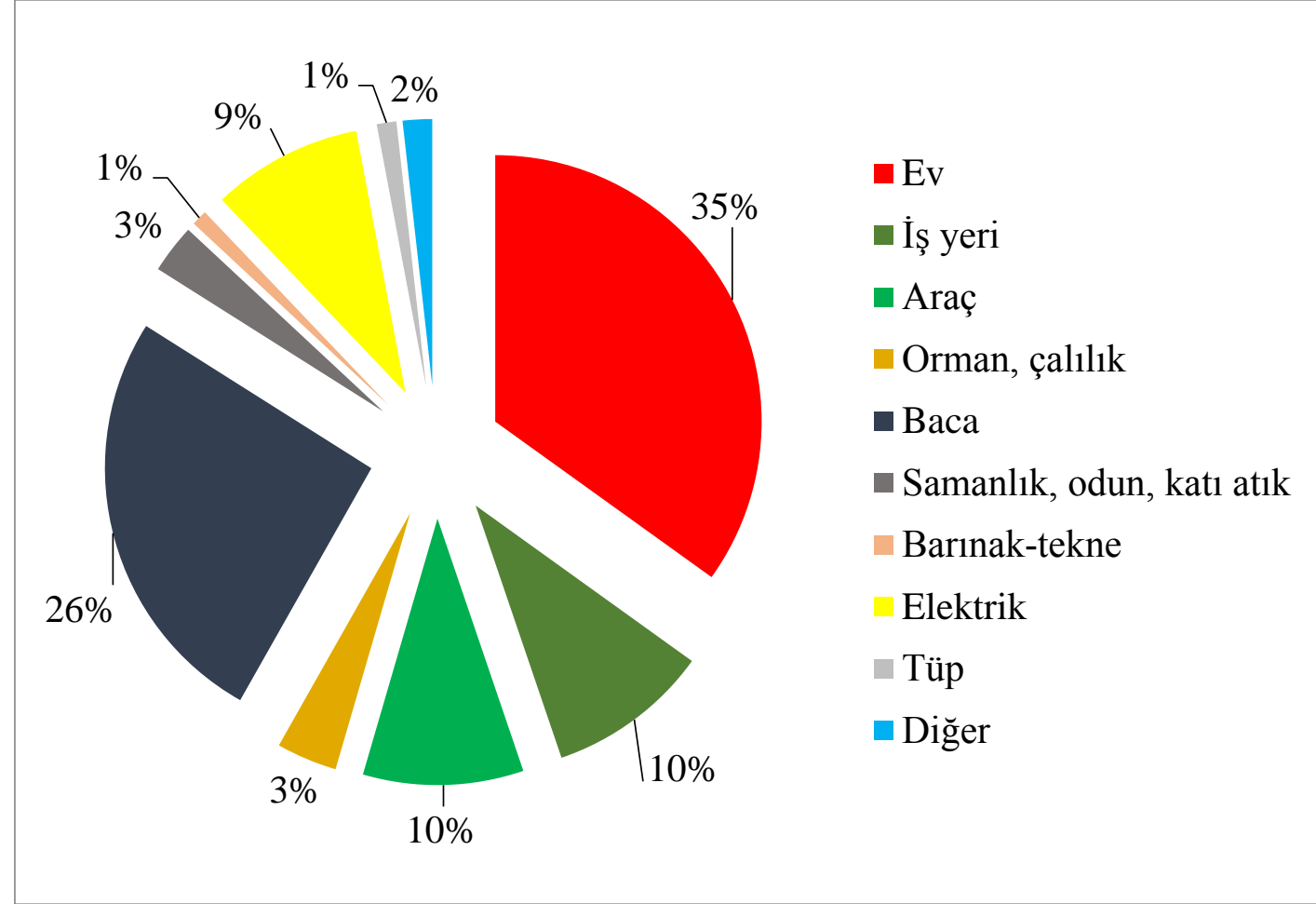

Şekil 2. Yangın türlerinin dağılımı, \% (2011-2016)

Meydana gelen yangınların çıkış sebepleri incelendiğinde (Şekil 3); ilk sırada \% 36 ile “elektrik kontağı”, ikinci sırada \% 27 ile "baca tutuşması”, üçüncü sırada ise \% 18 ile "dikkatsizlik" faktörlerinin olduğu görülmektedir.

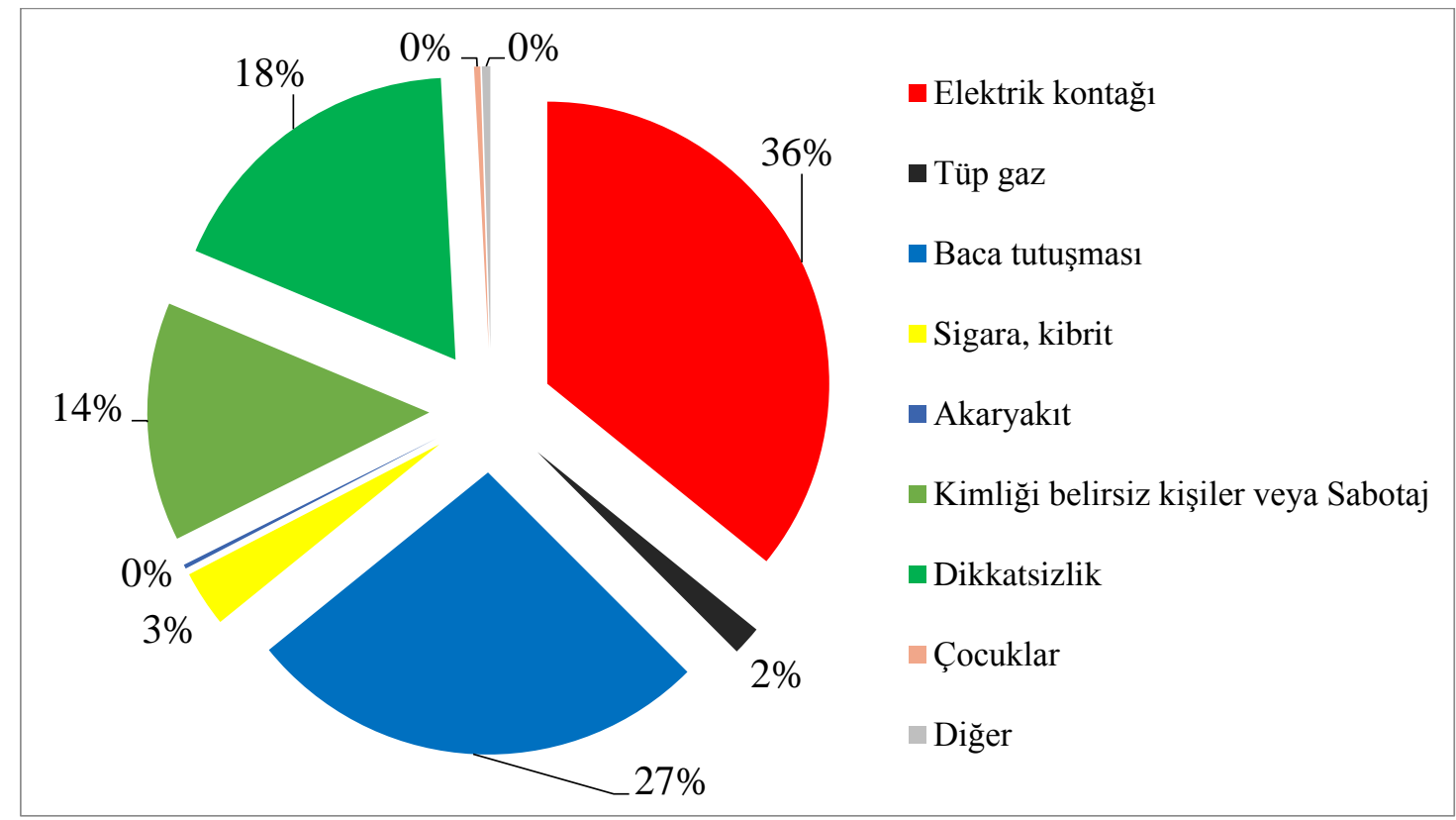

Şekil 3. Yangın çıkış sebeplerinin dağılımı, \% (2011-2016)

İtfaiye müdürlüğü tarafindan tutulan yangın istatistiklerinde itfaiyenin yangına müdahale durumu üç başlık altında ele alınmaktadır. Bunlar "Tamamen yanan”, "Kısmen yanarak kurtarılan" 
ve "Başlangıçta söndürülen" şeklindedir. 2011-2016 periyodunda meydana gelen 842 yangının \% 43'ü başlangıçta söndürülmüş, \% 37'si ise kısmen yanarak kurtarılmıştır. İtfaiye'nin yangın olaylarına müdahale durumunun yıllara göre dağılımı Şekil 4'te görülmektedir. Son 3 yılda “Başlangıçta söndürülen” yangın olaylarında artış olduğu göze çarpmaktadır.

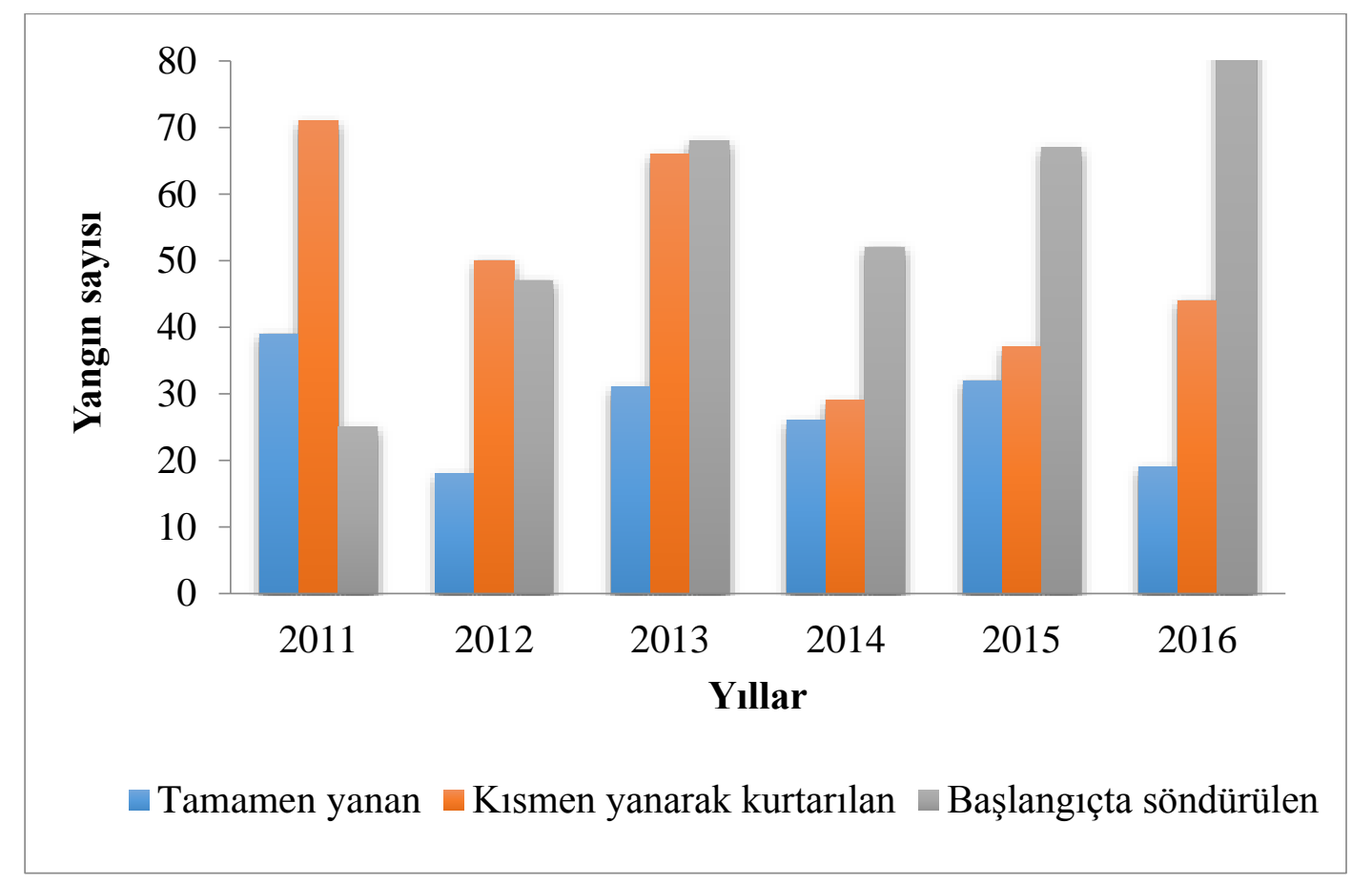

Şekil 4. Yangın müdahale durumunun yıllara göre dağılımı (tüm yangınlar)

Yangın sayılarının aylara göre dağılımını incelemek amacıyla Giresun Belediyesi İtfaiye'sine ait web sitesinde verileri bulunan 2012 yılı örneklem olarak seçilmiştir. İtfaiye toplamda 115 yangın olayına müdahale etmiştir. Yangın sayılarının aylara göre dağılımı Şekil 5'de görülmektedir. Yangın olaylarının ocak-şubat-mart aylarında artış gösterdiği diğer aylarda azaldığı görülmektedir. Bunun sebebi araştırıldığında yılın ilk 3 ayında meydana gelen yangınların çoğunluğunun sebebinin baca tutuşması olduğu belirlenmiştir. Mutfak aspiratörü ve bacalarda biriken is ve kurumlar zaman zaman tutuşmakta ve potansiyel yangın tehlikesi oluşturmaktadır. Oluşan bu kurumların tutuşması ile meydana gelen baca yangınları kolayca çatı yangınlarına, çatı yangınları da bina yangınlarına dönüşebilmektedir (URL-1, 2017). 


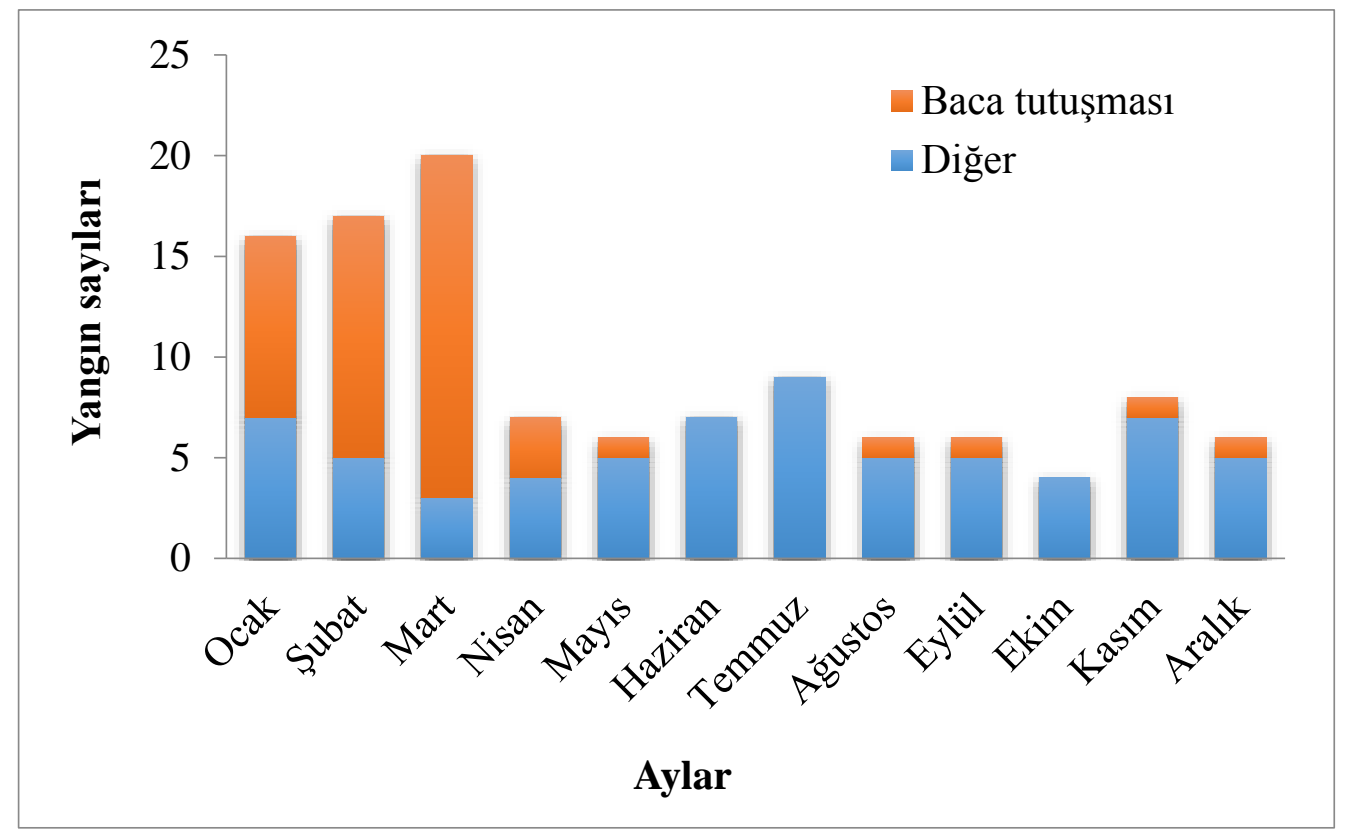

Şekil 5. Yangın sayılarının aylara göre dağılımı (2012)

\subsection{Konut Yangınları}

Konut yangınlarının yıllara göre dağılımı incelendiğinde (Şekil 6); 2011-2016 zaman aralığında toplam 294 adet yangın meydana gelmiştir. Konut yangınlarının "yanan yerin inşa malzemesine göre cinsi”ne göre dağılımı betonarme, ahşap ve kâgir ev kapsamında ele alınmış olup, yıllara göre dağılımı şekil 7'de görülmektedir. Son 6 yılda meydana gelen konut yangınlarının \% 67'si betonarme, \% 22'si ise ahşap yapı türünde gerçekleşmiştir.

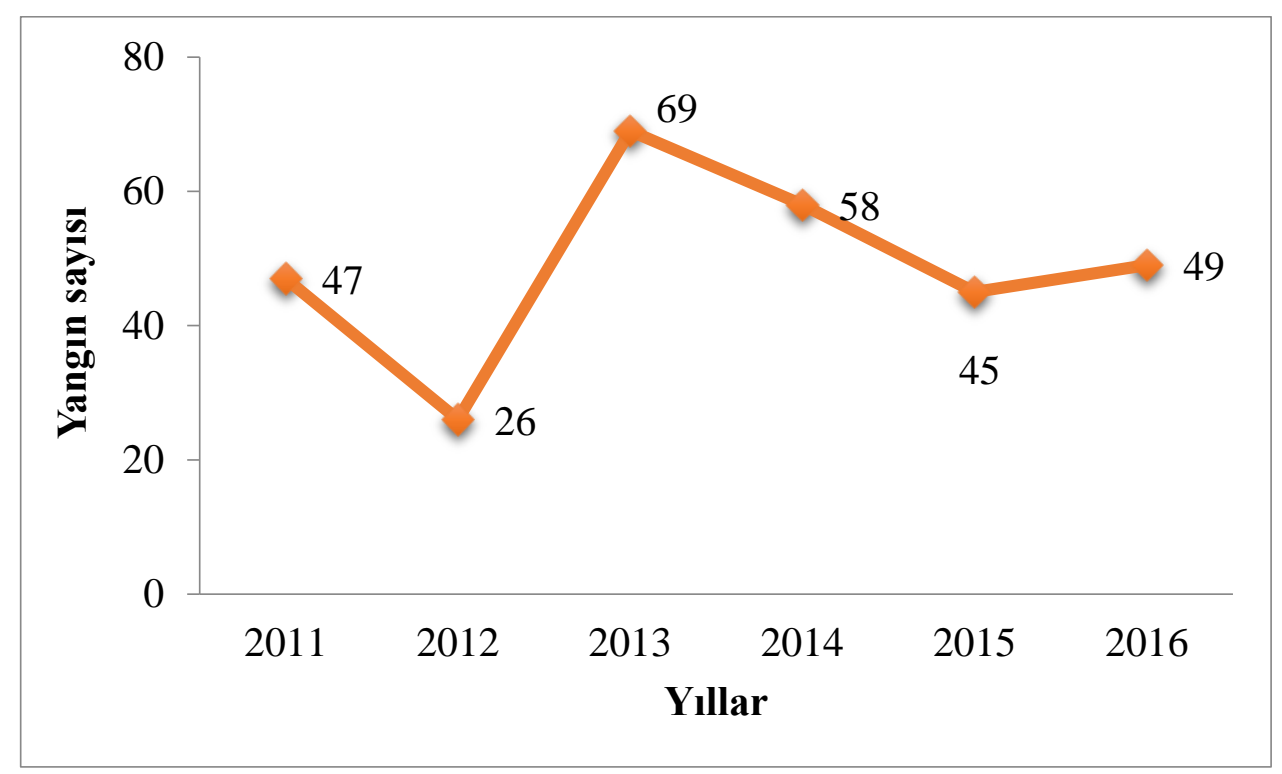

Şekil 6. Konut yangınlarının yıllık dağılımı. 


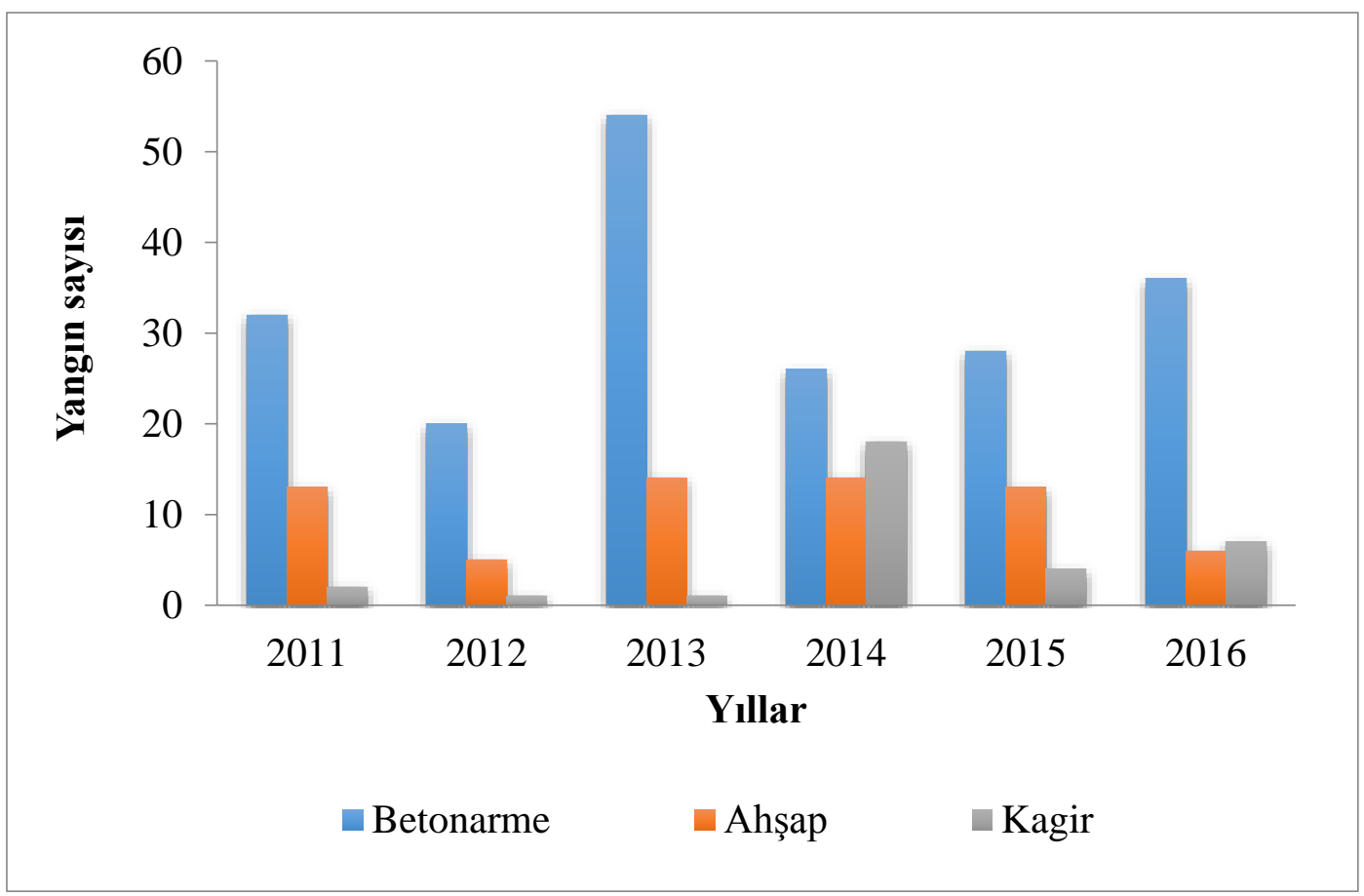

Şekil 7. Konut yangınlarının bina malzemesi türüne göre dağılımı.

Son 6 yılda meydana gelen konut yangınlarının çıkış sebeplerine göre y1llık dağılımı incelendiğinde (Şekil 8);

2011 yılında \% 58'inin elektrik kontağ 1 , \% 21 'inin dikkatsizlikten kaynaklandığı;

2012 yılında \% 46'sının elektrik kontağ 1 , \% 27’sinin kimliği belirsiz kişiler veya sabotajdan kaynaklandığ1,

2013 yılında \% 35'inin elektrik kontağ 1 , \% 25 dikkatsizlikten, \% 25'nin kimliği belirsiz kişiler veya sabotajdan kaynaklandiğ 1 ,

2014 yılında \% 48'inin kimliği belirsiz kişiler veya sabotaj, \% 26'sının elektrik kontağından kaynaklandiğ 1 ,

2015 yılında \% 40'nın elektrik kontağı, \% 29'unun dikkatsizlikten kaynaklandı̆̆ı,

2016 yılında \% 43'ünün elektrik kontağı, \% 39'unun dikkatsizlikten kaynaklandığı belirlenmiştir. 


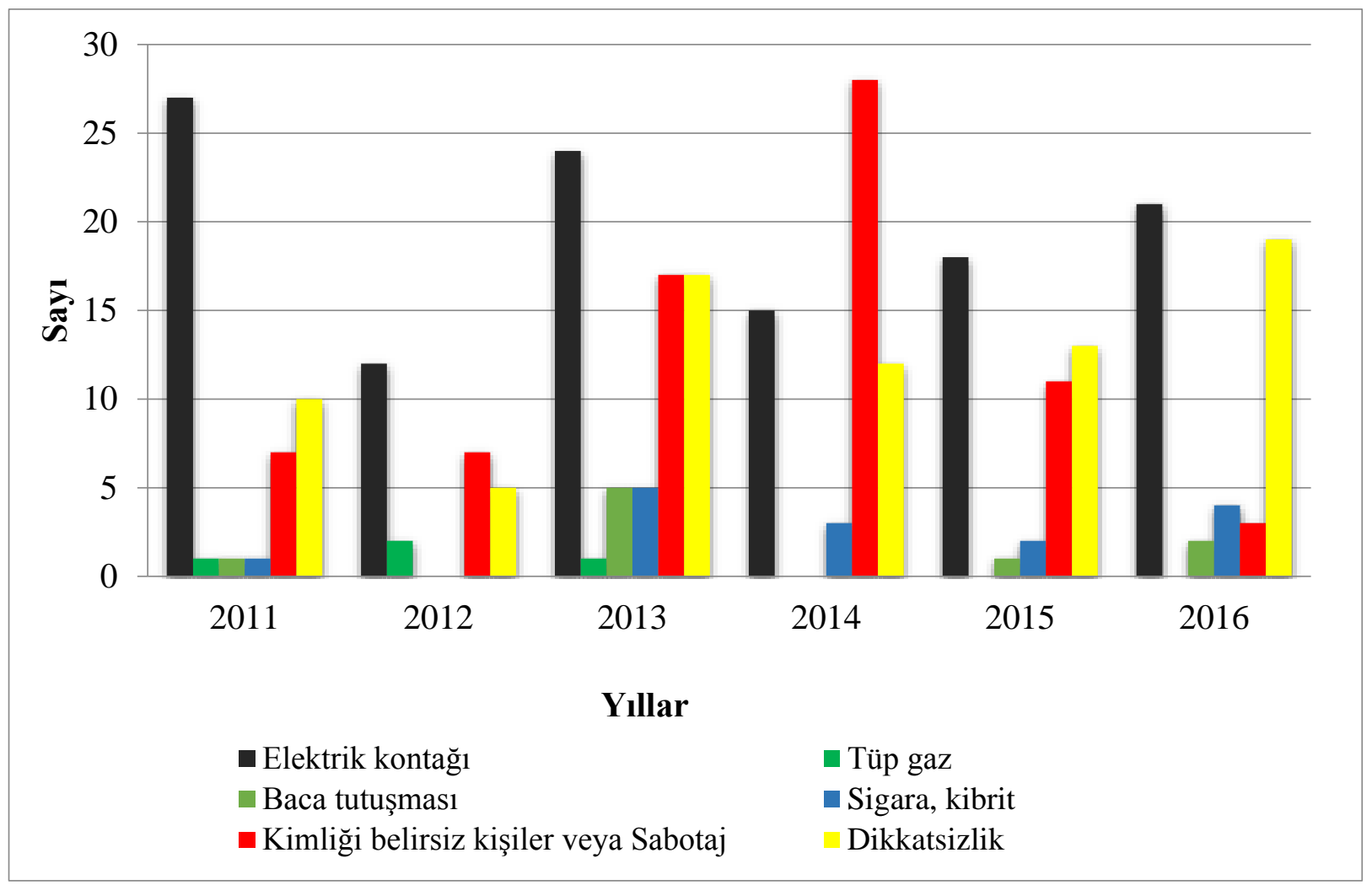

Şekil 8. Konut yangınları çıkış sebepleri

\section{Sonuçlar ve Öneriler}

Giresun ilinde meydana gelen yangınların 2011-2016 periyodunda incelendiği bu çalışmada;

- 6 yılda toplam 842 yangının meydana geldiği,

- Yangınların \% 35'ini konut yangınlarının oluşturduğu,

- Yangınların \% 36'sının çıkış sebebinin “elektrik kontağı” olduğu,

- Yangınların \% 43’ünün başlangıçta söndürüldüğü

belirlenmiştir.

2012 yılı yangın verilerine göre Giresun'da en çok yangın olayı ocak, şubat ve mart aylarında meydana gelmiş olup, bu artışı oluşturan sebebin "baca tutuşması" olduğu tespit edilmiştir.

Son 6 yılda Giresun'da meydana gelen konut yangınlarının sayısı 294 olup, bu yangınların \% 67'si betonarme yapı türünde meydana gelmiştir.

Yangın istatistikleri ile geçmiş durumların değerlendirilerek, geleceğe yönelik önlemler alınması oldukça önemli bir husustur. Giresun ili için elektrik kontağı ve baca tutuşması yangınları öncelikli olarak önlem alınması ve halkın uyarılması gereken sebeplerdir. Elektrik tesisatları standartlara uygun yapılmalı ve kullanımına dikkat edilmeli, bacalar düzenli aralıklarla kontrol edilmeli ve temizletilmelidir. 


\section{Teşekkür}

Yazar, verilerin temin edilmesinde yardımlarını esirgemeyen Giresun Belediyesi'ne teşekkürlerini sunar.

\section{Kaynaklar}

Ahrens, M. (2016). Fire Statistics and Fire Reports Home Structure Fires, NFPA (National Fire Protection Association) Retrieved from http://www.nfpa.org/news-and-research/fire-statistics-and-reports/firestatistics/fires-by-property-type/residential/home-structure-fires

Alkış, S. (2002). Otomobil Yangınlarının İncelenmesi, Adli Bilimler Dergisi, 1(2), 67-74.

Bekem, İ., Demirel, F., Çavuş, M. (2011, Ekim). Türkiye Ölçeğinde Yangın İstatistikleri Üzerine Bir Araştırma, Yangın ve Güvenlik Sempozyumu ve Sergisi (s. 195-201). İstanbul: Türkiye Yangından Korunma ve Eğitim Vakfi. .

Brushlinsky, N., Ahrens, M., Sokolov, S. and Wagner, P. (2016). World Fire Statistics, International Association of Fire and Rescue Services, No:21.

Bursa Büyükşehir Belediyesi İtfaiye Dairesi Başkanlığı (2011), Hizmet İçi Eğitim Ders Kitabı, Retrieved from http://itfaiye.bursa.bel.tr/wp-content/uploads/2011/11/Ders-kitabi-filigranli-2.pdf

Bursa Büyükşehir Belediyesi İtfaiye Şube Müdürlüğü. (2014). Durum Raporu, Retrieved from http://itfaiye.bursa.bel.tr/mudahale-sube-mudurlugu-nisan-ayi-yangin-istatistikleri.html 2014

İstanbul Büyükşehir Belediyesi İtfaiye Daire Başkanlığı (2015). Yangın ve Kazalarla Mücadele Eğitim Kitab1, Retrieved from http://itfaiye.ibb.gov.tr/img/1135817112015 9087030291.pdf

İzmir İtfaiye Daire Başkanlığı (2017). Genel İstatistikler-Yangın İstatistikleri, Retrieved from http://itfaiye.izmir.bel.tr/tr/IstatislikDetay/1322/9?AspxAutoDetectCookieSupport=1

Kocaeli Büyükşehir Belediyesi (2010). Temizlenmeyen Bacalar Yangın Sebebi, Retrieved from http://www.kocaeli.bel.tr/icerik/temizlenmeyen-bacalar-yangin-sebebi/36/21286

NFPA (National Fire Protection Association) (2016). Fire Statistics and Fire Reports Fires in US, Retrieved from http://www.nfpa.org/news-and-research/fire-statistics-and-reports/fire-statistics/fires-in-the-us

Türk Dil Kurumu. (2017). Güncel Sözlük "İstatistik”.

URL-1: http://www.ivak.org.tr/baca.html, (Erişim 10 Şubat 2017).

Yıldızbakan, A. K. (2001). İstatistik ve Ormancılıktaki Önemi, Doğu Akdeniz Ormancılık Araştırma Müdürlüğ̈̈ (Journal of DOA), 7, 113-125. 